\title{
PROUČAVANJE ŠKOLSKOG NEUSPEHA: DEFINISANJE, TRAGANJE ZA UZROCIMA, FAKTORIMA I MODELIMA PREDUPREĐIVANJA
}

\author{
Jelena Osmanović ${ }^{1}$, Nikola Simonović \\ Univerzitet u Nišu, Filozofski fakultet, Departman za pedagogiju \\ Univerzitet u Nišu, Filozofski fakultet, Departman za pedagogiju (student DAS)
}

\begin{abstract}
Apstrakt: Školski sistem kao skup vaspitno-obrazovnih očekivanja intencionalno ili bez ikakve namere stvara veštačku dihotomiju jednog fenomena $\mathrm{i}$ tako deli učenike u odnosu na obrazovna postignuća na uspešne i neuspešne. On je praktično fundamentalni i najbitniji pokazatelj i indikator obrazovnih dostignuća učenika iskazan u vidu školske ocene kao još uvek jedinog validnog i relijabilnog pokazatelja usvojenosti određenog kvantuma znanja ali sa druge strane, granica uspešnosti i neuspešnosti je veoma tanka i ne bi trebalo da bude shvaćena nekritički. Zato je potrebno demistifikovanje ovog problema i duboko preispitivanje uvreženog stava naučne javnosti o školi kao ,riznici znanja ${ }^{e e}$, neprikosnovenom liceju i jedinom ispravnom i valjanom putu saznavanja naučne istine i objektivne stvarnosti koja nas okružuje. Upravo iz tog razloga jedna ovakva analiza sadržaja može biti itekako i od praktičnog i od teorijskog značaja i dati svoj doprinos kao zamajac u rasvetljavanju ove problematike i u budućnosti. Pokušaj ove teorijsko-sadržajne analize da na jedan temeljan, studiozan, sveobuhvatan i interdisciplinaran način priđe veoma rasprostranjenom i delikatnom problemu, i analitički i sintetički se baveći opširnom i veoma raznovrsnom relevantnom literaturom, ukaže na pregršt varijeteta uzroka i faktora školskog neuspeha, ali i ukaže na ogroman značaj ranog otkrivanja i bespoštednog i sistematskog rada na predupređivanju i preveniranju ovog široko rasprostranjenog i opštedruštvenog problema.
\end{abstract}

Ključne reči: definisanje školskog neuspeha, uzroci školskog neuspeha, faktori školskog neuspeha, motivacija za postignućem, modeli predupređivanja

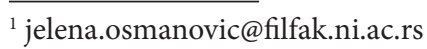




\section{Uvod}

Jedan od većih problema današnjice u svim vaspitno-obrazovnim institucijama je neuspeh učenika u školi, i to ne samo individualni, lični, već i mnogo širi - socijalni problem sa brojnim negativnim posledicama na ukupan razvoj ličnosti učenika, njegov budući život i svakako jedna od nepoželjnih pojava koju svi akteri vaspitnoobrazovnog procesa teže da u što većoj meri eliminišu. Moramo se složiti sa činjenicom da u velikoj meri, pa čak i nesagledivoj, nivo znanja, kvalitet usvojenosti i njegova operativnost, značajno utiču na dalji obrazovni razvoj, čine temelj budućeg školovanja i neodvojivi su segment jedne šire društvene odgovornosti.

Traganje za potencijalnim uzrocima, faktorima i modelima predupređivanja, njihovim složenim i uzajamnim relacijama, u moru nepregledne materije i neiscrpne naučne i stručne građe je obiman i težak zadatak ali istovremeno, smeo i hrabar poduhvat. Stoga smo se svojski potrudili da utvrdimo i ukažemo na sve moguće i mnogobrojne faktore, ključne razloge i uzroke koji utiču uzročno-posledično na obrazovno postignuće učenika i vode ka kontinuiranoj egzistenciji kategorije „,neuspešan učenik", jer neuspeh koji se pokaže na početku školovanja kasnije se teže otklanja ukoliko ne dođe do pravovremenih i adekvatnih reakcija.

Svi ovi činioci neizostavno, pojedinačnim delovanjem ili udruženim snagama, mogu predstavljati izvor saznanja od krucijalnog, esencijalnog i fundamentalnog značaja za strateško planiranje, utvrđivanje najadekvatnijih strategija koje će pomoći u prevenciji, otklanjanju i prevazilaženju tog problema koji je i te kako uzeo maha u vaspitno-obrazovnom procesu.

\section{Definisanje školskog neuspeha}

Pojam neuspeha, sam po sebi, veoma je širok i rasprostranjen zbog izuzetno velikog broja kauzalnih veza i isprepletanih odnosa. Uzevši u obzir činjenicu da je priprema mladih za život u društvu i osposobljavanje za rad opšti cilj školovanja, bitno je osvrnuti se na značaj poimanja uspeha kao generalno poželjne društvene vrednosti i neuspeha, kao njegovog antipoda, a samim tim i školskog neuspeha, kao jedne njegove komponente.

Školski neuspeh je aktuelan društveni problem i istraživači i teoretičari obrazovanja još uvek nisu postigli usaglašenost oko njegovog značenja (Smith, 2005).

Šaranović-Božanović (1984: 29) smatra da je ,,neuspeh - sinonim pojmu nenapredovanja, a i jedan i drugi se odnose na decu koja ne idu uporedo sa svojom uzrasnom grupom u školskom radu“. Neuspeh je viđen i kao razlika između očekivanog i ostvarenog postignuća učenika, pri čemu je očekivano određeno intelektualnim sposobnostima i skorovima na standardizovanim testovima postignuća (Thruman \& Wolfe, 1999).

Đorđević (1990) i Maksimović (2009) pod pojmom školski neuspeh, u najširem smislu, podrazumevaju opadanje postignuća u učenju, kao i pad određenog 
nivoa znanja. Postoje i autori koji smatraju da ,školska ocena nije jedini pokazatelj školskog uspehaee (Mavar, 2012: 49).

Konačna ocena, kao jedini pokazatelj ishoda učenja i kao osvedočena konstatacija usvojenog znanja ima višestruku ulogu, od motivacije do afirmacije, iskazuje takođe ,prednosti kontinuiranog vrednovanja rada“e (Stojanović, 2014: 417), međutim, ne možemo samo na osnovu nje suditi o učeniku i uzeti je u obzir kao jedinu i isključivu meru njegove (ne)uspešnosti.

Prema tome, neuspešan učenik nije nužno samo učenik koji ima slabe ocene. Svaki učenik koji je propustio da razvije i koristi sopstveni potencijal u cilju svog školskog napretka može se nazvati neuspešnim učenikom.

Oko definisanja pojma neuspeha slaže se nekoliko autora, koji neuspeh definišu i kao posledicu neusvojenih sadržaja, koji su u okviru svake škole propisani određenim planom i programom rada i na taj način dolazi do nemogućnosti zadovoljenja kriterijuma uspešnosti (Markovac, 1973; Pedagoški leksikon, 1996).

Pored već istaknutih definicija školskog neuspeha, možemo formulisati još precizniju definiciju ovog termina. Pod školskim neuspehom se podrazumeva nesklad između postignuća učenika i intelektualnih sposobnosti, neusklađenosti mogućnosti učenika i zahteva koji mu se postavljaju (Đorđević, 1990). Naime, učenici mogu imati izuzetno velike intelektualne sposobnosti, ali to ne mora značiti da će u školi postići uspeh u skladu sa svojim sposobnostima, jer postizanje uspeha pre svega zavisi i od motivacije, interesovanja, a nije uslovljen samo intelektualnim sposobnostima.

Pojedini autori (Malinić, 2009; Šaranović-Božanović, 1984) smatraju da je definisanje neuspeha kao posledice nedovoljno razvijenih intelektualnih sposobnosti i ostvarenog postignuća krajnje neprihvatljivo. Ovi autori pre svega uzimaju u obzir to da dete ne odrasta izolovano, već je deo kako uže tako i šire porodice, društva i čitave zajednice.

Šram i Futo (1988: 484) u svom koautorskom radu, koji se bavi školskim neuspehom smatraju ,da izraziti školski neuspeh predstavlja, u stvari, rezultantu određenih nepovoljnih porodičnih i socijalnih prilika u kojima učenici žive, naravno, pod uslovom da se ne radi o prisutnusti i deficijentnosti intelektualnih sposobnosti“".

Nakon izvršenog upoređivanja definicija školskog neuspeha, možemo uočiti da bez obzira na različito i mnogobrojno definisanje ovog pojma postoji izvesna povezanost i zajedničke karakteristike među istim. Na osnovu toga možemo reći da su neuspešni učenici oni koji u dovoljnoj meri i u određenom vremenskom roku ne savladaju nastavno gradivo. Zapravo, pokazatelj tome jesu negativne ocene, polaganje popravnih ispita i ponavljanje razreda kao ,svojevrstan dramatičan ishod, potpuni neuspeh i za učenika i za njegovo porodicue (Maksimović, 2009: 24).

Neuspeh, dakle, nije samo odgovornost neuspešnog učenika. Neuspeh može biti odraz neadekvatnih nastavnih planova i programa, udžbenika, sistema ocenjivanja i vrednovanja učeničkog postignuća. 


\section{Uzroci školskog neuspeha}

Proučavanju školskog neuspeha je neophodno prići sa više aspekata i multidisciplinarno da bi ovaj fenomen od opštedruštvenog značaja bio sagledan sveobuhvatno i da bi se proniknulo u srž samog problema.

Problem neuspeha je i danas prisutan u vaspitno-obrazovnoj praksi, usled toga što je njegovo sagledavanje u najvećem broju slučajeva svođeno samo na konstatovanje njegovog postojanja, pa je njegovo rešavanje prepušteno pojedinačnom delovanju ili se svodi na vršenje većeg pritiska na učenike.

Neuspeh učenika se definiše kao ,posledica jednog ili više uzroka, koje treba istražiti, imajući u vidu jedan složeni sistem različitih uzajamnih uticaja ličnosti učenika i osobenosti uslova u kojima se ona razvija“ (Šaranović-Božanović, 1984: 37). Naime, neuspeh ne može biti izazvan samo problemima u porodici ili pak problemima u školi ili među vršnjacima već on predstavlja čitav kompleks različitih uzroka koji ga izazivaju.

Malinić (2006: 229) široko definiše uzroke neuspeha navodeći nepovoljan opšti razvoj učenika, nepravilan odnos prema učenju, teškoće u usvajanju nastavnog sadržaja ali i ,lenjost, slabo predznanje, sredinu koja nije dovoljno stimulativna, loše uzore, nesređene porodične prilike, slabu organizaciju nastave, preobimne nastavne programe, nedostatak nastavnih sredstava, neadekvatne udžbenike“.

Sa druge strane, Šaranović-Božanović (1976: 9) uzroke neuspeha istražuje u okviru sledećih kategorija: ,porodice i neprilagođenosti porodičnoj sredini; subjektivnih faktora učenika; vaspitno-obrazovnih uticaja u okviru škole i neprilagođenosti školskoj sredini; društveno-ekonomskih odnosa ${ }^{e e}$.

Uzrok neuspeha u školi može biti posledica različitih ekonomskih i psiholoških faktora. Shodno tome možemo razlikovati sledeće kategorije uzroka neuspeha u školi (Maksimović, 2008) društveno-ekonomske; biološko-psihološke; uzroke pedagoškog karaktera.

Iz svega navedenog može se zaključiti da porodica i škola u najvećoj meri utiču na uspeh/neuspeh učenika u školi. Učenik koji odrasta u disfunkcionalnoj porodici ili se u školi oseća odbačeno i neprijatno, neće imati motivaciju i želju za napredak u školi.

U sklopu brojnih i različitih uticaja na mladu ličnost, porodica je bila i ostala izuzetno značajan faktor i najsigurniji saradnik škole, pa su i vaspitno-obrazovni uticaji njihova zajednička briga. Porodica i škola mogu svojim radom da ,pojačaju pozitivno dejstvo svih ostalih faktora, a svojim propustima u radu, mogu da otvore vrata za njihovo negativno delovanje" (Grandić, 2004: 370), a svakako su bez sumnje i neizostavno „najodgovorniji za obezbeđivanje vaspitnih modela i obrazovnih programa koji omogućavaju optimalni razvoj učenikae (Krnjajić, 2007: 99).

Kao poseban uzrok neuspeha učenika izdvaja se neadekvatan uticaj vršnjaka. Deca sa svojim vršnjacima, stvarajući snažno povezanu koheziju, pored vremena koje provode u školi, provode vreme i van nje. Učenici se mogu priključiti nekoj delinkventnoj grupi, još uvek eksperimentišući i pronalazeći sebe. Kvalitet interper- 
sonalnih odnosa između deteta i osoba iz njegovog okruženja predstavlja izuzetno značajan faktor kako kognitivnog tako i socioemocionalnog i moralnog razvoja svakog pojedinca (Krnjajić, 2007; Spasenović, 2003).

$\mathrm{Na}$ osnovu takvih stavova možemo zaključiti da su vršnjački odnosi od izuzetnog značaja za školsko postignuće jer podstiču motivaciju, razvoj intelektualnih sposobnosti što vodi visokom postignuću. Slobodno vreme i način njegovog korišćenja van škole mogu značajno da utiču na uspeh/neuspeh učenika u školi, pogotovo ako je to vreme u prekomernoj dozi i nesvrsishodno posvećeno korišćenju masmedija i interneta.

Razmatrajući čitavu paletu ostalih relevantnih potencijalnih uzroka, posvetićemo pažnju deci i omladini sa poremećajima u ponašanju. Bitno je napomenuti da kod autora Stakić i Stakić (2006: 23) pored niza problema nailazimo i na veoma značajne i vredne pomena, kao što su ,problemi koji prate opšte intelektualne sposobnosti, naročito verbalne, uspeh i ponašanje u školie koji su obično ispod proseka za uzrasnu grupu deteta sa izraženim poremećajem u ponašanju". Možemo konstatovati da takvi poremećaji u ponašanju deteta mogu u značajnoj meri remetiti funkcionisanje i postignuće u školi, dalje profesionalno obrazovanje, društvenu svrsishodnost $i$ ostvarenost.

Poremećaj pažnje sa hiperaktivnošću (PPHA) koji se ogleda u „visokom stepenu energije, neumornosti, uskim obimom i trajanjem pažnje i koncentracije sa čestim padovima u njihovom nivou i kvalitetu" (Jevtić i Knežević-Florić, 2011: 6), takođe može biti potencijalni uzrok školskog neuspeha i i te kako uticati na njegovo ispoljavanje kao aktivnog poremećaja u socijalnom ponašanju.

Prilikim obuke čitanja već u prvom razredu osnovne škole može doći do izvesnih problema koji ako se ne otkriju na vreme i ne radi se na njihovom sistematskom otklanjanju mogu u krajnjoj instanci dovesti do slabijeg školskog postignuća tj. školskog neuspeha u kraćem ili dužem vremenskom intervalu. Jedan od takvih evidentnih potencijalnih problema i uzroka obrazovnog nepostignuća je disleksija kao poremećaj u učenju čitanja i pored postojanja normalne inteligencije, dobrog vida i sluha, sistematske obuke, adekvatne motivacije i ostalih povoljnih edukativnih, psiholoških i socijalnih uslova i takvu decu i adolescente prate pored bihejvioralnih, emocionalnih i socijalne poteškoće (Bošković, 2012; Milićević i Milošević, 2019). Kao specifična teškoća u učenju školskih veština čitanja, postavlja ograničenje u primeni različitih tehnika i procedura proveravanja i ocenjivanja postignuća učenika.

Postavlja se pitanje da li i levorukost može biti potencijalni uzrok školskog neuspeha ako se posmatra kao problem, kao pojava koja odstupa od uobičajene, ako se posmatra kao „hendikep”, kao izvor neprijatnosti i podsmevanja u školi, iako je ovaj fenomen čvrsto utemeljen na biološkim i fiziološkim teorijama i može biti posmatran na potpuno drugačiji način u smislu darovitosti i posebnosti. Kod levoruke dece, kada se od njih prisilno zahteva upotreba desne ruke, kod učenja početnog pisanja dolazi do različitih slučajeva poremećaja u čitanju i pisanju, tzv. legastenija ili disleksija, odnosno grafastenija ili disgrafija“ (Grandić, 2004: 257). Komentar koji ide u prilog veličanja i opravdanja levorukosti je ,da su oni kreativniji, umetnički nastrojeni, individualniji i inventivniji od desnorukuh"e (Morris, 2005: 345). 
Deca sa razvojnim smetnjama, takođe zbog specifičnosti i delikatnosti svojih poteškoća u razvoju mogu biti potencijalno neuspešna, tj. imati slabije školsko postignuće. Poznato je da takvu decu prati izvesna stigmatizacija u školskom i vanškolskom, užem i širem okruženju, pa je iz tog razloga neophodno raditi na uklanjanju takvog negativnog obeležavanja i društvenog diskriminisanja i u radu sa ovom populacijom trebalo bi sprovoditi princip individualizacije i diferencijacije kao jednog od najznačajnijih aspekata savremene nastave, ali i celokupnog vaspitno-obrazovnog i pedagoško-psihološkog rada. I pored činjenice da je intelektualni hendikep trajna a ne prolazna kategorija i shvatanja da ,sve što je različito, što odstupa od proseka i postavljenih normi, nije prihvaćeno, smatra se nepoželjnim, odbacuje se ili ",nasilno" uklapa u šablon" (Milutinović, 2012: 65), postojanje inkluzije ukazuje na to da je društvo prihvatilo hendikep. Deca neprilagođena zahtevima škole i deca koja zaostaju u nastavi - slabi učenici koji pohađaju redovnu školu u osnovi su deca koja nisu ovladala čitanjem i pisanjem na predviđenom nivou i najčešće pokazuju teškoće upravo u čitanju, pisanju, matematici (Hrnjica, 1997). Ova kategorija dece je potencijalno predodređena na školski neuspeh a razlozi su raznovrsni poput teškoća u rešavanju zadataka zbog slabe koncentracije, preskakanja slova i perseveracije u pisanju, neadekvatnom verbalnom izražavanju, motoričkoj usporenosti i brzog zamaranja. Sa naglaskom da bi razvoj ove dece koji odstupa od normalnog trebalo shvatiti kao jedan delikatan, drugačiji i specifičan, a ne kao defektan razvoj, iako se u stručnoj literaturi koja se bavi defektološkom problematikom može pronaći stav da se svaki „organski nedostatak, ili mana realizuje kao socijalna nenormalnost ponašanja"e (Vigotski, 1996: 54).

\section{Faktori školskog neuspeha}

Doživljaj neuspeha u školi nesumljivo može imati nesagledive posledice i dalekosežne socijalne implikacije ukoliko se trajno učvrsti kod učenika. On može delovati tako da budi nesigurnost, stvara otpor ka učenju, budi negativne emocije, kao što su bes, ljutnja, podstiče na distanciranje od nastavnika, otuđenja od njega kao bitne figure u njegovom vaspitanju i obrazovanju, stvaranja animoziteta prema njemu, averzije prema nastavi, indiferentnosti prema nastavnim predmetima i sadržajima, kreiranja generalno jedne iskrivljene i negativne predstave o školi.

Učenici sa nedovoljnim školskim uspehom najčešće na neuspeh reaguju tako što ih on obeshrabruje, dovodi do slabljenja i/ili potpunog gubitka samopouzdanja, motivisanosti, i u priličnoj meri destimuliše za dalji rad. „Nastavnik predstavlja ključnu tačku nastavnog procesa. On je organizator i poderator celokupnog rada, partner i saradnik. U tom kontektu veoma su bitne promene u radu samog nastavni$\mathrm{ka}$, širina u pristupu i sagledavanje ličnosti tokom svih faza nastavnog procesa (Stojanović, 2013). Sa druge strane možemo dodati misli autora Stojanovićeve (2014: 420) koja govori da ,aktivno učestvovanje u nastavi, povećanje intrinzične motivacije, individualni pristup dobodi do povećanja uspeha".

Krneta (2000: 21) vrši podelu faktora koji utiču na neuspeh učenika, u tri grupe: faktori koji proizilaze iz delovanja šire ili uže socijalne sredine na pojedinca; 
faktori koji proizilaze iz ličnih karakteristika nastavika kao ocenjivača i faktori koji proizilaze iz osobina učenika“".

Malinić (2009: 81) navodi sledeće značajne faktore koji mogu uticati na ispoljavanje školskog neuspeha: ,faktore porodične sredine; faktore školske sredine; personalne faktore učenika"e.

U istraživanju (Šaranović-Božanović, 1984: 33) došlo se do prilično široke liste vanškolskih faktora za koje se može pretpostaviti da bi mogli uticati na slab uspeh i identifikovani su sledeći: „somatski status, zdravstveno stanje, problemi u porodici, broj članova porodice, odnos među roditeljima, odnos roditelja prema deci, intelektualni nivo roditelja, ekonomsko stanje porodice, aspiracije i društveni položaj porodice, udaljenost kuće od škole, opterećenost drugim obavezama“.

Kao značajan faktor na nivou škole koji utiče na uspeh/neuspeh učenika izdvaja se kvalitet nastavnog rada (Malinić, 2009), ali i nastavni program i karakteristike udžbenika (Maksimović, 2009).

Vaspitni stil nastavnika u zavisnosti da li on u svom radu primenjuje autoritaran, autoritativan (demokratski) i ravnodušan može uticati na uspehu učenika. Uspeh koji će učenici u nastavi postići zavisi od psihološko-pedagoške kompetentnosti nastavnika, motivisanosti, ali i od primerenosti nastavnih sadržaja razvojnim karakteristikama učenika, od stepena individualizacije i diferencijacije u nastavi.

Kada sagledavamo uspeh i neuspeh kao dva neodvojiva pola jednog pedagoškog ali i psihološkog fenomena moramo napomenuti da su oni veoma bitni činioci daljeg napredovanja u učenju i da su učeničke reakcije na uspeh tj. neuspeh različite s obzirom na njihove individualne osobenosti.

Među najznačajnije, a samim tim i osnovne psihološke faktore, koji utiču na uspešnost učenja, ubraja se motivacija. Ona predstavlja jedan izuzetno kompleksan pojam, a pored toga i snažno podsticajno sredstvo, pokretačku snagu i nagon koji podstiče pojedinca na delovanje i akciju (Lungulov, 2010). Kod motivisanog učenika veći je i misaoni napor i stepen misaone aktivnosti, a samim tim i veća koncentracija prilikom učenja što dovodi do veoma dobrih i zapaženih rezultata u učenju.

Nasuprot tome, kod učenika koji su okarakterisani kao neuspešni uočava se problem sa koncentacijom vezano za učenje, i sa tenacitetom tj. postojanošću i usredsređenošću pažnje na zadatak, tj. informaciju, ali i vigilnošću odnosno pokretljivošću i gipkočću pažnje i sposobnošću brzog prenosa sa jedne informacije na drugu, kao osnovnih elemenata pažnje.

Pored uspeha, tj. neuspeha u učenju koji predstavlja temu našeg razmatranja, kao osnovna sredstva motivacije i podsticaja koja mogu imati bitnu ulogu u stvaranju preduslova za uspešnost učenja, navode se „cilj ili namera da se nešto nauči, rok, interesovanje, prijatnost, neprijatnost i stav prema gradivu, poznavanje rezultata, pohvala i pokuda, nagrada i kazni, saradnja i takmičenje kao i stepen aspiracije (Vučić, 1989: 74; Danilović, 1998: 169).

Takođe, saopštavanje rezultata postignutih u toku učenja može apsolutno biti jedna sigurna vodilja i trasirati put ka uspehu i posebno zadovoljavanja ne samo spoljašnje već i unutrašnje - intrinzične motivacije i njenog daljeg razvijanja. 
Kada govorimo o profesionalnom razvoju nastavnika i svrsi refleksivne prakse u njihovom individualnom i stručnom usavršavanju, važno je ukazati na ,značaj osvešćivanja, upoređivanja, preispitivanja implicitnih teorija i namera i njihovog dovođenja u vezu sa postignutim rezultatima“" (Radulović, 2011: 75), a sa tim u vezi školskim postignućem, kao i važnosti sagledavanja vlastitog načina delovanja, boljeg razumevanja sebe i daljeg ličnog stručnog usavršavanja. Nastavnici moraju biti „eksperti u jednom ili više predmeta, stalno unapređivati svoja znanja, upotpunjavati svoje predmetne ekpertize pedagoškim sposobnostima, uključujući i motivaciju za učenje, kreativnost, saradnju, razumevanje socijalnog konteksta obrazovanja“" (Maksimović, 2011: 111). Za nastavnike je možda od ključnog značaja za njihov profesionalni razvoj da kontinuirano evaluiraju svoj rad, što dalje implicira da kontinuitet u vrednovanju učeničkih postignuća i uspeha (Vrcelj, 1996) dovodi do dugoročnih rezultata. Za postizanje kvalitetnog znanja neophodan je i kvalitetan nastavnik i njegov kontinuirani profesionalni razvoj sagledan kroz koncept celoživotnog učenja (Stojanović, 2014).

Motivacija za učenje može biti vidno oslabljena delovanjem raznih distraktivnih faktora, ukoliko je nastava monotona i jednolična a znanja se usvajaju isključivo pukim mehaničkim ponavljanjem i memorisanjem uz očigledno misaono pasiviziranje učenika.

Moramo se složiti da današnjom nastavom dominira prilagođavanje nivoa prezentovanja nastavnih sadržaja i usvajanje znanja potrebama tzv. ,,prosečnog učenika"e, iako je poznato da takav učenik ne postoji i da je on ustvari fikcija, puka teoretska zamisao stručnjaka" (Suzić, 2005: 39). Takvu nastavu odlikuju monotonost i demotivisanost za bolje učenike, preteškost i nejasnoća za slabije, što dalje implicira ,da ona nije prilagođena sposobnostima, potrebama i interesovanjima svakog učenika ponaosob i sputava ga da napreduje individualnim tempom shodno svojim mogućnostima" (Stanković, 2005: 6).

Kvaščev (1981) na bazi istraživanja u oblasti psihologije stvaralaštva, ukazuje na izvesnu povezanost motivacionih faktora, samim tim i motiva postignuća, sa osobinama ličnosti, kao značajnih komponenata stvaralačkih sposobnosti, uz naglašavanje postojanja individualnih razlika kod pojedinaca.

Interesovanje za faktore školskog postignuća predstavlja jedno od dominantnih područja pedagogije obrazovanja i sasvim je jasno zašto se školska postignuća zapravo predstavljaju kao najprepoznatljivija mera kvaliteta obrazovanja u vaspitno-obrazovnom procesu.

\section{Predupređivanje školskog neuspeha}

Rad na predupređivanju školskog neuspeha mora biti sistematski i organizovan na svim nivoima, počev od porodice, škole, pa do šire društvene zajednice.

Kako bi se iskorenio problem neuspeha učenika u školama, upotrebljavaju se sredstva i metode u nastojanjima predupređivanja i suzbijanja školskog neuspeha i to njegovim ranim otkrićem, tj. identifikacijom uzroka i faktora koji dovode do njega, a 
potom organizovanja i sprovođenja aktivnosti koje imaju za cilj suzbijanje delovanja identifikovanih uzroka. Sa naglaskom sagledavanja problema sa svih strana. Podrška neuspešnim učenicima dugo vremena bila je glavna, ako ne i primarna, uloga stručnih saradnika (Gutvajn i Ševkušić, 2013).

Kao standardni načini suzbijanja školskog neuspeha navode se (Maksimović, 2009) dopunska, produžena nastava i ponavljanje, razreda a u literaturi pronalazimo stav koji govori o tome da se ,ponavljanje ne može prihvatiti kao pedagoška mera, jer se na taj način negira uspeh učenika iz svih predmeta a samim tim, to je degradacija ličnosti deteta“ (Šaranović-Božanović, 1976: 8).

Takođe, uloga porodice kao bazičnog okruženja u kome se ličnost deteta formira i razvija, u prevenciji školskog neupeha je ogromna i nesagledivih razmera. Obrazovni nivo roditelja je izuzetno značajan prediktor školskog postignuća dece. Viši nivo obrazovanja roditelja je bitan činilac koji stimuliše roditelje da rade sa svojom decom i na taj način sarađuju i sa školom.

Odnos učenika i nastavnika, koji treba biti zasnovan na demokratiji, razumevanju i strpljenju, istinskoj veri u njegove potencijale, podsticanju i motivisanju na predan rad i trud je najvažniji za predupređivanje školskog neuspeha. Ukoliko ima adekvatan odnos sa učenikom, nastavnik će lakše saznati uzrok njegovog neuspeha, kao i način njegovog prevazilaženja.

Kod autora Maksimović (2009: 193) pronalazimo širok i raznovrstan dijapazon načina eventualnog suzbijanja učenika: ,više učiti i pažljivije slušati na času; individualni pristup svakom učeniku; obraćanje pažnje na ličnost učenika; povećati broj časova dopunske nastave; povremeno motivisati učenika; stalno raditi na istraživanju uzroka neuspešnosti; uvažavajući učenikove potrebe ${ }^{\text {ee }}$ ali i češće anketirati neuspešne učenike, konsultovati roditelje, opremiti škole savremenijom opremom kao mogućim merama u cilju poboljšavanja učeničkog uspeha.

U svetlu razmatranja tematike predupređivanja neuspeha Šaranović-Božanović (1976) ističe primenu teorije etapnog formiranja umnih radnji koja vodi delotvornijem usvajanju pojmova i uspešnijem formiranju samih misaonih procesa, kao nastavnog modaliteta koji posebno obraća pažnju na suštinsku povezanost učenja i razvoja, u smislu naglašene stalne težnje i stremljenja ka ,zoni narednog razvoja ${ }^{e e}$.

Šre i značajnije pedagoške implikacije mogu se ogledati u i situaciji da učenik nije samo na reproduktivnom nivou već i da maksimalno angažuje svoje inteletualne potencijale kao nešto invarijantno u sebi i sve više je okrenut ka potpunijoj i intenzivnijoj misaonoj aktivizaciji (Bakovljev, 1982). Zato je prisutno sve beskompromisnije zalaganje od strane svih stručnih saradnika za sticanjem znanja i saznavanja objektivne stvarnosti vlastitim intelektualnim radom i angažovanjem svih raspoloživih unutrašnjih potencijala učenika.

Saradničko učenje može takođe imati značajan udeo i doprineti poboljšanju i eventualnom otklanjanju ovog problema, kao „sastavni deo aktivne nastave orijentisane na delovanje i uspeh podstičući aktivni karakter učenja i prema njemu oblikujući uslove učenja"e (Maksimović, 2012: 216). U tom kontekstu Rojders (Roeders, 2003 ) ističe da saradničko učenje u svim svojim oblicima i svim nastavnim predmetima dalo bolje rezultate od klasične nastave što se ogleda u pismenom izražavanju, retoričkom fondu, opštoj informisanosti, uspehu iz matematike. 
Budući da je neuspeh problem celokupnog društva a ne samo učenika kao individue neophodno je preusmerenje svih raspoloživih snaga, potencijala i unutrašnjih rezervi pojedinaca na predupređenje ovog fenomena. Saradnja porodice kao uzora i modela detetu za usvajanje društveno-socijalnih oblika ponašanja i škole kao najvažnije društvene institucije gde se ti oblici šire i produbljuju u suzbijanju školskog neuspeha je nemerljiva, $i$ ta saradnja mora biti na najvišem mogućem nivou i predstavljati dugoročni cilj za uspeh i napredak.

\section{Zaključak}

Sagledavanje problema školskog neuspeha se ni u kom slučaju ne sme svesti samo na konstatovanje da takav problem u školama postoji, da predstavlja određenu pojavu koja se javlja usled nedovoljnog rada učenika.

Neuspeh u školi se ne javlja naglo i odjednom, već prolazi jedan takoreći gradacijski put. Neuspeh je takav proces koji se odlikuje izuzetnom dinamikom i podložnošću za promene (Šaranović-Božanović, 1984). Period školovanja može imati veoma dramatičan razvojni tok ukoliko je učenik konstantno izložen pritisku od eventualnog neuspeha i nepostizanja unapred predvidjenih i zacrtanih obrazovnih postignuća i rezultata.

Naime, reč je o tome da treba obratiti pažnju na najranije oblike javljanja neuspeha kako bi se još u tom početnom obliku utvrdilo koje su strategije najedekvatnije za otklanjanje mogućih uzroka neuspeha i prevencije ovog dugogodišnjeg problema u školama.

Trajniji neuspeh kod učenika postaje izuzetno štetan za njihov psihički razvoj, a porvh svega dovodi i do opadanja motivacije i interesovanja za učenje. $U$ tom smislu neuspeh u školi može dovesti do raznovrsnih posledica. Međutim to ne znači da učenike stalno moramo štititi od doživljavanja neuspeha, jer ukoliko nauče da se efikasno izbore sa svakom teškoćom na koju naiđu i nađu načine da se izbore sa svakim problemom biće jači i istrajniji, a to je sve siguran put ka uspehu.

Česta je pojava da se kod omladine javlja problem nepostojanja jasne direkcije ka nečemu, manjak usredsređenosti, to jest, kada na vidiku nema cilja. U raskoraku između detinjstva, kod kojeg u prvo vreme uopšte nema ciljeva i rane zrelosti, koja sama po sebi imanentno iziskuje određenost, mladi se, tokom svog razvojnog puta, susreću sa raznim preprekama i barijerama i često, zbog razočarenja nastalih neostvarenjem visokih ambicija i ideala, postavljaju sebi skromnije ciljeve „spuštajući, pritom, nivo aspiracije“ (Allport, 1969: 382).

Pristup traganju uzroka, faktora i načina za predupređivanje školskog neuspeha se mora shvatiti kao svojevrstan interdisciplinarni konglomerat, da bi ova problematika bila sagledana u potpunosti, sveobuhvatno i na adekvatan način. Kriterijumi školskog uspeha/neuspeha su podložni promenama i uslovljeni su u potpunosti društvenim kretanjima pa se tako o učeničkim postignućima ne može suditi ad hoc, već se moraju uzeti u obzir subjektivne i objektivne mogućnosti učenika, njegova ličnost i široka skala činioca poput okolnosti u školi, nastavnih planova i programa, 
nastavnih sadržaja i celokupnog vaspitno-obrazovnog rada, široke lepeze činioca van škole, a ne samo uskog posmatranja ovog fenomena kroz prizmu kvantiteta $\mathrm{i}$ kvaliteta usvojenog znanja, umenja i veština.

Teorijskom analizom možemo konstatovati da samo izuzetno ozbiljan pristup učenju i školskim obavezama, samostalan, planski, organizovan, intencionalan rad, sa puno volje, želje i htenja, daje dobre rezultate i obezbeđuje uspeh sa generalnog stanovišta, a u krajnjoj instanci i školski uspeh. Neuspeh, kao posledica pogrešnog izbora, neozbiljnosti i/ili nepažnje je, svakako, verni pratilac radikalnih i hrabrih rešenja. Svaki propust ako se posmatra kao prolazna kategorija, pa i propust u školskom postignuću, može se popraviti i unaprediti ako se deluje preventivno i na vreme otkriju pravi razlozi, uzroci i faktori koji dovode do školskog neuspeha.

Studije u oblasti istraživanja školskog neuspeha posebno u eksplorativnom domenu mogu se u budućnosti projektovati na nastojanja preciznijeg određivanja kauzalnih veza i odnosa između uzroka, faktora kao prediktora školskog neuspeha.

\section{Literatura}

Allport, W. G. (1969). Sklop i razvoj ličnosti. Beograd: Kultura.

Bakovljev, M. (1982). Misaona aktivizacija učenika u nastavi. Beograd: Institut za pedagoška istraživanja.

Bošković, D. (2012). Problem disleksije i načini njegovog prevazilaženja u nastavi stranog jezika. Komunikacija i kultura online, III (3), 221-256.

Danilović, M. (1998). Tehnologija učenja i nastave. Beograd: Institut za pedagoška istraživanja i Zrenjanin: Tehnički fakultet „Mihajlo Pupin“e.

Đorđević, J. (1990). Intelektualno vaspitanje i savremena škola. Beograd: Zavod za udžbenike i nastavna sredstva i Sarajevo: Zavod za udžbenike i nastavna sredstva „Svjetlost ${ }^{\mathrm{ee}}$.

Grandić, R. (2004). Prilozi porodičnoj pedagogiji. Novi Sad: Izdanje autora.

Gutvajn, N. i Ševkušić, S. (2013). Kako stručni saradnici doživljavaju školski neuspeh učenika. Zbornik Instituta za pedagoška istraživanja, 45 (2), 342-362. Beograd: Institut za pedagoška istraživanja.

Hrnjica, S. (1997). Deca sa posebnim potrebama - Dete sa razvojnim smetnjama u osnovnoj školi. Beograd: Učiteljski fakultet.

Jevtić, B. i Knežević-Florić, O. (2011). Izazovi socijalnopedagoške delatnosti: sa hrestomatijom. Niš: Filozofski fakultet.

Krneta, Lj. (2000). Faktori školskog uspjeha. Banja Luka: Banjaluka kompani.

Krnjajić, S. (2007). Pogled u razred. Beograd: Institut za pedagoška istraživanja.

Kvaščev, R. (1981). Psihologija stvaralaštva. Beograd: Zavod za udžbenike i nastavna sredstva.

Lungulov, B. (2010). Motivacija učenika u nastavi - pretpostavka uspeha u učenju. Pedagoška stvarnost, 3-4, 294-305. 
Maksimović, J. (2012). Unapređivanje saradničkog učenja u školi posredstvom akcionih istraživanja. Naučni skup „Nastava i učenje - ciljevi, standardi, ishodiee, 215-228. Užice: Učiteljski fakultet.

Maksimović, J. (2011). Stavovi nastavnika prema istraživanju vaspitno-obrazovne prakse u školi. Radovi Filozofskog fakulteta (Filozofske i prirodno-matematičke nauke), 13 (II), 111-125. Pale: Filozofski fakultet.

Maksimović, J. (2009). Različiti metodološki pristupi u istraživanju školskog neuspeha. Niš: Filozofski fakultet.

Maksimović, J. (2008). Prilog istraživanju školskog neuspeha. Pedagoška stvarnost, vol. 54, 5-6, 450-464.

Malinić, D. (2009). Neuspeh u školskoj klupi. Beograd: Institut za pedagoška istraživanja.

Malinić, D. (2006). Uzroci školskog neuspeha. U S. Krnjajić (Ur.): Pretpostavke uspešne nastave (229-254). Beograd: Institut za pedagoška istraživanja.

Markovac, J. (1973). Suzbijanje neuspeha u osnovnoj školi: Prikaz pedagoškog istraživanja Zavoda za unapređivanje osnovnog obrazovanja SR Hrvatske. Beograd: Jugoslovenski Zavod za proučavanje školskih i prosvetnih pitanja.

Mavar, M. (2012). Školski neuspjeh i ovisničko ponašanje. Jastrebarsko: Naklada Slap.

Milićević, M. i Milošević, N. (2019). Bihejvioralne, emocionalne i socijalne teškoće dece i adolescenata sa disleksijom i smetnjama u razvoju govorno-jezičkih sposobnosti. Zbornik Instituta za kriminološka i sociolška istraživanja, vol. XXXVIII, 1, 99-111. Beograd: Institut za kriminološka i sociolška istraživanja.

Milutinović, S. (2012). Priroda i neki uzroci teškoća u vaspitanju dece sa smetnjama u razvoju. Istraživanja u pedagogiji, II (2), 65-98. Beograd: Časopis srpske akademije obrazovanja i Vršac: Visoka škola strukovnih studija za obrazovanje vaspitača ,Mihailo Palov".

Morris, D. (2005). Otkrivanje čoveka - Vodič kroz govor tela. Niš: Zograf.

Pedagoški leksikon (1996). Beograd: Zavod za udžbenike i nastavna sredstva.

Radulović, L. (2011). Obrazovanje nastavnika za refleksivnu praksu. Beograd: Filozofski fakultet.

Roeders, P. (2003). Interaktivna nastava. Beograd: Institut za pedagogiju i andragogiju.

Smith, E. (2005). Analysing Underachievement in Schools. London: Continunum International Publishing Group.

Spasenović, V. (2003). Vršnjačka prihvaćenost/odbačenost i školsko postignuće. Zbornik Instituta za pedagoška istraživanja, br. 35, 267-288, Beograd: Institut za pedagoška istraživanja.

Stakić, Đ. i Stakić, M. (2006). Planiranje i programiranje vaspitno-terapeutskog rada sa decom i omladinom sa poremećajima u ponašanju,emocionalnom i socijalnom razvoju -priručnik za stručnjake u socijalnoj zaštiti i maloletničkom pravosuđu. Beograd: Ministarstvo rada, zapošljavanja i socijalne politike Republike Srbije.

Stanković, Z. (2005). Primena nastave na više nivoa složenosti multimedijalnim pristupom. Niš: Filozofski fakultet i Niš: Prosveta.

Stojanović, D. (2014). Kontinuirana provera znanja u savremenom visokoškolskom muzičkom obrazovanju kao prediktivna uspešnost studenata. U Bojana Dimitrijević (Ur) 
Nauka i savremeni univerzitet 3, Savremene paradigme u nauci i naučnoj fantastici, 409-422. Niš: Filozofski fakultet.

Stojanović, D. (2013). Holistički pristup nastavnika u procesu ocenjivanja uspešnosti studenata u muzičkom obrazovanu. Zbornik radova Visoke škole strukovnih studija za obrazovanje vaspitača. 1, 26-46,

Suzić, N. (2005). Pedagogija za XXI vijek. Banja Luka: TT-Centar - Teacher Training Centre.

Šaranović-Božanović, N. (1984). Uzroci i modeli prevencije školskog neuspeha. Beograd: Prosveta.

Šaranović-Božanović, N. (1976). Mogućnost predupređivanja neuspeha u nastavi primenom teorija etapnog formiranja umnih radnji. Beograd: Prosveta.

Šram, Z. i Futo, A. (1988). Školski neuspeh kao antecendens društveno neprihvatljivog ponašanja dece i omladine. Pedagoška stvarnost, 7-8, 483-499.

Thruman, R., \& Wolfe, K. (1999). Improving academic achievement of underachieving students in a heterogeneous classroom. Illinois, US: Master's Action Research Project, Saint Xavier University and IRI/Skylight.

Vigotski, S. L. (1996). Osnovi defektologije. Beograd: Zavod za udžbenike i nastavna sredstva.

Vrcelj, S. (1996). Kontinuitet u vrednovanju učenikova uspjeha. Rijeka: Pedagoški fakulet Sveučilišta u Rijeci.

Vučić, L. (1989). Pedagoška psihologija: Učenje. Beograd: Savez društava psihologa SR Srbije.

\title{
ANALYZING SCHOOL FAILURE: DEFINING CAUSES AND FACTORS AND SEARCHING FOR PREVENTION MODELS
}

\author{
Jelena Osmanović, Nikola Simonović \\ University of Niš, Faculty of Philosophy, Department of Pedagogy \\ University of Niš, Faculty of Philosophy, Department of Pedagogy (PhD student)
}

Abstract: The school system comprises a set of educational expectations which, intentionally or accidentally, create an artificial dichotomy of a phenomenon, and thus divide students with respect to educational attainment into successful and unsuccessful ones. It is a fundamental and essential indicator of students' educational achievement, expressed in the form of a school grade as the only valid and reliable indicator of the acquisition of a certain quantum of knowledge. On the other hand, the dividing line between success and failure is very thin and should not be taken uncritically. Therefore, it is necessary to demystify this problem and to re-examine thoroughly the well-established attitude of the scientific public towards school as a "treasure trove of knowledge", the absolute lyceum, and the sole correct and valid way of attaining the 
scientific truth and the objective reality that surrounds us. It is for this reason that such content analysis can be both practical and theoretical in nature and can contribute to illuminating this issue in the future. The attempt of this theoretical content analysis to approach a quite widespread and delicate problem in a thorough, meticulous, comprehensive and interdisciplinary way by synthetically analyzing extensive literature points to a variety of causes and factors of school failure, but also points to the enormous importance of early detection and the uncompromising and systematic work on preventing this widespread problem.

Keywords: Defining school failure, causes of school failure, factors of school failure, achievement motivation, models of prevention.

\section{Citiranje članka:}

Osmanović, J. i Simonović, N. (2019). Proučavanje školskog neuspeha: definisanje, traganje za uzrocima, faktorima i modelima predupređivanja. Godišnjak za pedagogiju, 4(2), 45-58 